Canadian Journal of Higher Education Revue canadienne d'enseignement supérieur

Volume 42, No. 2, 2012, pages 49-66

\title{
Derrida in the University, or the Liberal Arts in Deconstruction
}

Colm Kelly

St. Thomas University

\begin{abstract}
Derrida's account of Kant's and Schelling's writings on the origins of the modern university are interpreted to show that theoretical positions attempting to oversee and master the contemporary university find themselves destabilized or deconstructed. Two examples of contemporary attempts to install the liberal arts as the guardians and overseers of the contemporary university are examined. Both examples fall prey to the types of deconstructive displacements identified by Derrida. The very different reasoning behind Derrida's own institutional intervention in the modern French university is discussed. This discussion leads to concluding comments on the need to defend pure research in the humanities, as well as in the social and natural sciences, rather than elevating the classical liberal arts to a privileged position.

\section{RÉSUMÉ}

Le compte-rendu de Derrida sur les écrits de Kant et de Schelling portant sur les origines de l'université moderne démontre que des positions théoriques tentant de surveiller et de gouverner l'université contemporaine se trouvent déstabilisées et déconstruites. L'auteur étudie deux exemples de tentatives contemporaines visant à donner aux arts libéraux le statut de gardiens et de surveillants de l'université contemporaine. Les deux exemples en question ne tiennent pas la route devant les substitutions déconstructives identifiées par Derrida. On y discute le raisonnement fort différent derrière l'intervention institutionnelle au sein d'universités françaises modernes propre à Derrida. Cette discussion mène à des commentaires conclusifs sur le besoin de défendre la recherche pure dans les sciences humaines, sociales et naturelles, plutôt que d'élever les arts libéraux classiques à un rang privilégié.
\end{abstract}




\section{INTRODUCTION: CHAMPIONING THE LIBERAL ARTS}

A defence of liberal arts education always implies a diagnosis of the contemporary university and usually implies a diagnosis of the surrounding society. ${ }^{1}$ For example, Nussbaum (2010) argues that humanities education is under threat in a society that places too much emphasis on the type of knowledge that contributes directly to the economy. An education in the humanities is an "education for democracy" (the title of her second chapter); that is, its purpose is educating citizens rather than training workers. Thus are an analysis and diagnosis of the university developed and a diagnosis of contemporary society implied. The argument, about both the university and the wider society, is effectively encapsulated in Nussbaum's title: Not for Profit: Why Democracy Needs the Humanities. The details of her argument (e.g., p. 45-46, 27ff., 47ff., 95ff.) concern, for example, the need to learn to see the world from the viewpoint of others, to overcome feelings of disgust for stigmatized minorities, for education in the arts in order to cultivate the imagination, and for critical thinking or Socratic argument. Despite what is engaging and thought-provoking in her argument, it is difficult to see how to deduce from this argument criteria for the aims of liberal education, and for the curriculum that would meet those aims. One can imagine many other needs added to those Nussbaum discusses, and one can imagine some inspired by a more conservative or a more radical political sensibility than hers. From the start, she assumes a humane and liberal sensibility, and a belief that the humanities are morally salutary. The arguments derived from these assumptions will be unlikely to persuade those who do not share, or are opposed to, such assumptions.

Fish's (2008) slightly earlier intervention in the same terrain helps clarify what is problematic about Nussbaum's approach. Fish argues that the university and its disciplines have their own internal logic and coherence, and that they do not need an external moral or political rationale to justify their existence and functioning. The purpose of a university, he explains, is to introduce students to the knowledge and traditions of inquiry of the disciplines, and to teach them the analytical skills to be able to negotiate their way in those disciplines. Fish insists that these skills are all a university should attempt to teach. Any attempts to engage in moral education or to promote civic responsibility or to inculcate a taste for social justice will fail. The scientific and scholarly disciplines are not designed for these tasks, which Fish implies are matters for socialization, not for education. Furthermore, professors are not qualified to engage in moral education, and if they were trained for this role, they would no longer be professors, but would be more like "moralists" and "therapists" (p. 14). At this point, the contrast with Nussbaum becomes instructive. Once the division of the university into specialized disciplines is acknowledged, the result is that any systematic attempt to construct a core curriculum for purposes of moral and civic education then appears to be arbitrary. The university simply is an institution with a highly developed division of intellectual labour, and no account of a core curriculum as moral education can fundamentally alter this division of labour. The implication is that this division of intellectual labour-along with a highly developed level of specialization across all the institutional spheres of society-is a core feature of modernity and cannot be wished away. This is not to say that universities cannot be persuaded to adopt modest curricular reform, such as increasing breadth require- 
ments; however, a full-scale attempt to develop a core curriculum would require that one discipline or one set of disciplinary concerns would have to rule over the other disciplines. Any such attempt is more likely to result, not in a shared culture, but in strife.

The premise of what follows is that most attempts to revivify the liberal arts and humanities are caught at a kind of tension or switching point between the positions represented by Nussbaum and Fish. The appeal that the liberal arts should form a core curriculum of moral education runs against the grain of the specialization and division of labour characteristic of modernity. However, the intellectual specialization characteristic of modernity seems to call out for an account of intellectual activity which gathers together or unifies the specialized disciplines, and it is to this call that liberal arts advocates respond.

This paper gradually outlines an alternative to either position: a deconstructive approach that sustains an affirmative questioning of the founding assumptions of the specialized disciplines, and at the same time refrains from ushering in a unifying synthesis of the disciplines. The paper proceeds as follows. The first section provides an account of selected aspects of Derrida's contributions to debates about the university, focusing on Derrida's reading of the writings of Kant and Schelling, which roughly correspond respectively to Fish's position on the division of intellectual labour, and to Nussbaum's call for an education that transcends this division of labour. The upshot of Derrida's account is that all positions attempting to oversee and master the contemporary university find themselves destabilized or deconstructed. The second section examines two contemporary attempts to install the liberal arts as the guardians and overseers of the contemporary university, and shows how these examples fall prey to the types of deconstructive displacements identified by Derrida. The final section briefly discusses the reasoning behind Derrida's institutional intervention in the modern French university. This discussion contrasts with the liberal arts advocacy discussed in the previous section and leads to concluding comments about the need to defend pure research in the humanities, and in the social and natural sciences, rather than elevating the classical liberal arts to a privileged position.

\section{DERRIDA ON THE UNIVERSITY}

In a paper from 1980, Derrida presents some interpretations of Kant's 1798 essay, The Conflict of the Faculties. Derrida (2004a, citing Kant, 1979, p. 23) quotes the opening passage of the essay, in which Kant describes the modern university of specialized disciplines. ${ }^{2}$ The university, Kant tells us, is "a public means for treating the sum of knowledge... in a quasi-industrial manner, with a division of labour where, for as many fields as there may be of knowledge, so many public teachers would be allotted." The university would have autonomy, "for only scholars can pass judgment on scholars as such." It would be divided into faculties; that is, "various small societies into which university teachers are divided, in keeping with the variety of the main branches of knowledge." These faculties would be authorized to "admit... student-apprentices from the lower schools aspiring to its level," and also to grant to teachers who are "not drawn from the members themselves... a universally recognized rank (conferring upon them a degree)-in short, creating [them as doctors]" (p. 84). This description seems to be a remarkably accurate representation of the structure of the modern university, which was just then coming into existence. Derrida (2004a) reminds us of the analogy Kant draws between this modern university and the industrial society then being established, a society that would create the University of 
Berlin within 10 years of Kant's writing, a university that was the first and still is the most imposing model of the modern university.

This is the model of the university which Fish inherits and defends, but Kant explicitly poses the question Fish sets aside or neglects. What orders and regulates the relations between specialized disciplines? Whenever a man-made or artificial institution, such as the university, is founded on the idea of reason, then its specific organization, while appearing to be merely empirical or happenstance, will have an a priori rational character (Derrida, 2004a, p. 85, citing Kant, 1979, p. 31). This rationality will be evident in the relations between the different faculties. Kant distinguishes between the higher faculties of law, theology, and medicine, and the lower faculty of philosophy. The higher faculties are considered higher by the wider society because they are involved in the exercise of power, while the philosophy faculty is considered lower because of its lack of power. The higher faculties are required to produce useful knowledge concerning the running of society, and so will not have unlimited freedom. The lower faculty, in contrast, is concerned only with truth, and so must be totally free when it comes to judgments of truth. For example, the theologian is not allowed to question the existence of God, nor the medical doctor the value of health. The philosophy faculty, again in contrast, is the embodiment of the idea of reason which governs the university. The university is the idea of reason institutionalized; moreover, the philosophy faculty is that institutionalization of reason par excellence. The philosophy faculty, therefore, ought to control the higher faculties with respect to truth. That is, philosophy has the right to legislate over, or judge, the claims to truth that the higher faculties make. But philosophy judges not only the higher faculties of law, medicine, and theology. Philosophy itself is divided into two departments: historical knowledge (for example, history, geography, philology, and the humanities, along with the empirical knowledge of the natural sciences) and pure rational knowledge (for example, pure mathematics, pure philosophy, and the metaphysics of nature and of morals). The philosophy faculty therefore "extends to all parts of human knowledge" and "can, therefore, lay claim to any teaching, in order to test its truth" (Kant, 1979, p. 45).

Although prescient in his description of the quasi-industrial division of labour in the new type of university, Kant's account of philosophy in the German university seems very dated. We know that the scope and power of philosophy has shrunken enormously since Kant's time, and even in his time the claim that the discipline could legislate over the natural sciences seems unfounded. However, Derrida implies that it would be wrong to interpret Kant's argument as being about philosophy in a literal or disciplinary sense. Derrida (2002, citing Kant, 1979, p. 9) argues that Kant is referring to philosophy as a discipline, of course. Less literally, Kant is also referring to reason as the tribunal that judges the reasonableness of anything at all: "Such a tribunal is all powerful 'by right' and 'in principle,' since it does not claim to judge this or that, or particular 'books' or 'systems,' but rather, Kant specifies, it judges 'the faculty of reason in general'" (p. 56) Thus Kant is referring to reason as the legislator or judge of what is reasonable. If we substitute in Kant's argument the idea of the power of reason as the judge of what is reasonable, what Kant is saying seems no longer anachronistic, but instead, Derrida argues, powerfully predictive or descriptive of the modern university. Whoever judges the truth of a statement has placed him or herself in the position not only of judging the truth of that statement, but also of judging the truth of truth, or of being the legislator of truth: 
A philosopher speaks and acts thus, whether he is a philosopher by profession or not... . This is the case, occasionally, of no matter whom, or very often, of the representative of a non-philosophical discipline, a historian or a jurist, a sociologist, a mathematician, a logician, a philologist, a grammarian, a psychoanalyst, a literary theorist. This philosopher who puts forward, explicitly or implicitly, in the broad or strict sense, the question quid juris does not content himself with examining a judgment or pronouncing the law at work in an established field. He prepares himself to pronounce the law (on the subject) of the law. (Derrida, 2001, p. 58-59)

Derrida hints here that the Kantian tribunal of reason is not stable. More than one discipline or school can lay claim to being the tribunal of reason. Derrida shows that this instability is already there in the texts of Kant. We can approach this issue by asking, Where is philosophy located? It is the tribunal of reason and oversees all forms of knowledge. This characterization would imply that philosophy should not be located in any one place; that is, it should not have a department of its own. In Kant's account, in addition to philosophy overseeing everything within the university, there is in the university both a faculty of philosophy, which itself contains many areas that would now be separate disciplines, and several departments of philosophy within that faculty. As Derrida (2004a) puts it, philosophy is both the whole and part of the whole: "And so the whole forms an invaginated pocket inside every part or subset" (p. 106). This invaginated topology is widespread. A particular discipline or family of disciplines within the university and just a part of the university-the liberal arts being the case in point-is claimed to be the central discipline which gathers together, oversees, or makes meaningful the educational tasks of all the other disciplines. This discipline or family of disciplines is in turn claimed as that which will allow the university to be the remedy for the ills of the larger society of which the university is just a part.

Before turning in the next section to comment on this destabilization or delocalization of the tribunal of reason in relation to the modern liberal arts, it is necessary to turn to Derrida's analysis of the major alternative to Kant's understanding of the university, at the time of the founding of the University of Berlin. This alternative to, and reaction against, Kant came to be known as German Romanticism (Humboldt, 1970; Schaffer, 1990). Derrida (2004b) examines this reaction against Kant by discussing F. W. J. Schelling's (1803/1966) "Lectures on the Method of University Studies." Schelling's objection to Kant's model of the university (and to the Kantian critical philosophy more generally) is that it divides the university-into faculties, departments, and so on-without thinking through what substantively underlies the various divisions. That is, the divisions are overcome only in the formal sense of each faculty submitting to shared rules of reason. Schelling instead wants to think through the "originary unity" which "makes dissociation itself thinkable and possible" (Derrida 2004b, p. 67, original emphasis). Derrida (2004c) quotes Schelling (1966, p. 11): "The aptitude for doing thoughtful work in the specialized sciences, the capacity to work in conformity with that higher inspiration which is called scientific genius, depends upon the ability to see each thing, including specialized knowledge, in its cohesion with what is originary and unified" (p. 131). Schelling goes on to say that "whatever is incapable of fitting harmoniously within that budding, living totality is a dead shoot which sooner or later will be eliminated by organic laws" (p. 131). This theme, 
Derrida tells us, is "the rhetoric of naturalism, organicism, or vitalism as it plays upon the theme of the complete and interdisciplinary unity of knowledge, the theme of the university as an organic social system" (p. 131).

Of particular interest are the consequences Schelling draws from this theme for the place of philosophy in the university. Schelling proposes that there should be no department of philosophy. If philosophy is what thinks through and embodies the originary and organic unity of all the bodies of knowledge into one body, then it cannot be located in one place, since it must be everywhere: "That which is all things cannot for that very reason be anything in particular" (Schelling, 1966, p. 79, cited in Derrida, 2004b, p. 72). For Schelling, philosophy is not a specialized discipline, but instead is the process of forming the unity of knowledge and culture across science, art, and poetry; that is, the very process of formation, or Bildung, or unifying translation between one field and another. He suggests that instead of a faculty of philosophy, there can only be a faculty of arts (Schelling, 1966, p. 73). Strictly speaking, there should not be a single, localized, locatable faculty of arts either, because the process of forming the unity of knowledge this faculty represents must also occur everywhere, and not just in one faculty or department. Nevertheless, one can see that the faculty of arts in a modern North American university might resonate with Schelling's analysis more than would professional or applied faculties. Derrida (2004b) points out that Schelling recalls the collegium artium to which Kant had also referred: a liberal institution that would not appoint doctores, but magistri, or teachers of liberal arts, and would avoid the bureaucratic organization of the university.

Ultimately, according to Derrida, Kant's and Schelling's topology of the university and the place of philosophy in it, while seeming to be opposing views, also share something important. Philosophy should be everywhere and thus nowhere, says Schelling. Philosophy should oversee everything, says Kant, and in so doing, Derrida implies, it is in danger of moving dangerously about, displacing and disseminating itself. Elsewhere, Derrida (2002) refers to an "essential unrest of philosophical identity" (p. 7). Here he implies that there is an essential instability to the location of philosophy. It cannot know one place, or rest in one place. This analysis is Derrida's deconstruction of the place of philosophy in the schema or system of the university. Philosophy destabilizes or dislocates itself. In advance, it is displaced from its place. It would be wrong to think that Derrida is simply advocating this displacement and dislocation. Instead, this displacement is simply what happens or takes place. The deconstructively oriented philosopher, or humanities scholar, or sociologist is not imposing this displacement, but is reminding us that it is already underway; that we are already on the way to being out of place. The questions would then be how we relate ourselves to, or how we negotiate with, or how we conduct ourselves in relation to, this displacement.

\section{THE LIBERAL ARTS IN DECONSTRUCTION}

Philosophy, in its dominant traditions, locates itself as the leading form of knowledge and wisdom, as we have seen in different ways with Kant and Schelling. Derrida also discusses the theme of the dominance of philosophy in relation to professional education. He notes that commentators as different as Kant, Nietzsche, and Heidegger, among others, have insisted that professional education must be of secondary importance in the university, and that pure or disinterested thought is the core of the university. This hierarchy, 
Derrida (2004c) tells us, repeats the "profound and hierarchizing political evaluation of metaphysics" (p. 151), referring to Aristotle's Metaphysics. At the top of the hierarchy, according to Derrida, is theoretical knowledge. It is knowledge of causes and principles, which have priority over merely useful knowledge. The person who has this theoretical knowledge "is the leader or architekton of a society at work" (p. 152). He is situated above the manual labourer who produces without theoretical knowledge, produces naturally, like a fire burns. This "theoretician-leader" is "in essence a teacher" (p. 152). Because he understands causes and principles, he can transmit knowledge rather than merely practise a craft. "To teach, then, and at the same time to direct, steer, organize, the empirical work of the labourers. The theoretician-teacher or architect is a leader because he is on the side of the arkhe, of beginning and commanding" (p. 152). He understands the reasons for things. Because he "answers to the principle of reason, which is the first principle, the principle of principles," he "takes orders from no one; it is he, on the contrary, who orders, prescribes, lays down the law" (p. 152). This hierarchy of knowledge not only implies a hierarchy of commanding and obeying, but also needs a social hierarchy to create the conditions for the production of theoretical knowledge. A leisure or priestly caste is required that has the time to devote to theoretical knowledge, beyond the immediate concerns of pleasure or necessity, and the implication is that this leisured stratum must be supported by the productive strata of society.

Derrida is not condemning this hierarchy as such. He is instead indicating that this implied social, political, and epistemological hierarchy is carried along with, and by, the internal logic of the modern university, and he is warning that attempts to rethink or reform the university should be aware of the risks of reconstituting or strengthening this hierarchy. However, notable among defenders of the liberal arts is the explicit repetition and valorization of this hierarchy. The liberal arts are claimed to know the essential principles for studying humanity, and on this basis they claim the right to direct, control, and judge the other disciplines.

Such a claim is particularly evident in a book implicated in the history of St. Thomas University, the institution sponsoring these reflections on the liberal arts, and of which the current author is a faculty member. The book is entitled Liberal Education and Value Relativism: A Guide to Today's B.A., by Myers, Malcolmson, and O'Connell (1996). Myers and Malcolmson have until recently successively held the position of vice-president academic for many years at St. Thomas University. This book proposes an uncompromising vision of its subject, repeating uncritically a received version of central themes from ancient Greek philosophy. Liberal education is concerned with the question of what the good life is for human beings, and the good requires us "to act in accordance with principles" and to "choose sound principles" (p. 7). The goal of a liberal education is to discover and teach these sound principles and to cultivate "a taste for the beautiful, the noble, the true and the good." Liberal education is the "highest, the noblest, and the most fully human form of education" (p. 18).

Having elevated their own vision of education to the highest level, Myers et al. find most of the existing disciplines more or less inadequate. For example, natural science is characterized as a primarily technological enterprise that produces "technical specialists who can put the discoveries of modern science to work in our economy," and that sets aside the "moral and metaphysical significance" (p. 68) of scientific discoveries. In a 
similar vein, social science is characterized as aiming at "discovering new techniques for solving practical problems, for making our world more efficient, more comfortable and more prosperous" (p. 71). In each case, the pursuit of comfort and prosperity is contrasted with the noble aims of a true liberal education. This contrast is particularly evident in their characterization of psychology: "Modern academic psychology has been very successful in its new technological role. The research undertaken by academic psychologists has led to all sorts of discoveries that make our world a safer, healthier, and more efficient place. But students who seek a liberal education will find few psychology courses that will aid them in their quest for human wisdom" (p. 72). Thus is reproduced in entirely uncritical terms what Derrida describes as the founding gesture of metaphysics referred to above, the valuation of thinking; that is, of the search for principles and causes, over and above what is characterized as the unthinking pursuit of the lower needs of comfort, health, and so on. This hierarchy and its attendant luxury is explicitly valorized by Myers et al.: "Liberal education is perhaps the greatest of luxuries in our modern world. It is a luxury in that, with no promise of any economic return, it costs a great deal of time and money; and, more importantly, it is a luxury in the sense that it is a prize of incomparable worth" (p. 18).

It is important to note what is at stake here. Myers et al. support a particular hierarchy of the disciplines. Other disciplines, from physics, to biology, to sociology or economics, have their own more or less implicit attitudes to their neighbouring disciplines, and an implicit model of a hierarchy of knowledge. The classical liberal arts advocates, however, have in addition a political theory that calls on them to put into effect and to institutionalize their hierarchical vision of the disciplines. The practitioners of the mainstream arts and sciences, whatever their implied or even stated views on the relative value of the different disciplines, have a common commitment to shared procedures of reasoning and inquiry. This formal commitment to procedural rationality allows for mutual tolerance of substantively very different fields of inquiry. The classical liberal arts advocates are, in contrast, committed to a substantive hierarchy of the disciplines forever at odds with the actual constitution of the disciplines. This division into disciplines, as the discussion of Kant indicated, already has old and deep roots, and cannot, nor should not, be willed away. The classical liberal arts advocates are therefore permanently at odds with the enlightenment and post-enlightenment division of the university into the liberal arts and sciences, and have a political theory to motivate them to pursue the case.

Kant (1979) had argued that the conflict between the higher faculties and the philosophy faculty could never end, because the philosophy faculty would always have to interrogate the truth claims of the higher faculties: "The philosophy faculty can never lay aside its arms in the face of the danger that threatens the truth entrusted to its protection, because the higher faculties will never give up their desire to rule" (p. 55). Given that philosophy has been displaced from its regulative position, and given that the advocates of the classical liberal arts repeat uncritically the hierarchy of knowledge and the accompanying socio-political hierarchy of ancient philosophy, it is more likely today that it is they who "will never give up their desire to rule"; that is, to regain their former hegemony. For Kant the conflict between the higher and lower faculties was a regulated conflict. He likened the conflict to that between the government party and the opposition party in parliament; that is, between parties who ultimately had the same goals. The conflict can be characterized, says Kant, as concordia discors, discordia concors: discordant harmony, 
harmonious discord. However, those who see themselves, like the St. Thomas University liberal arts advocates, as pursuing "the most fully human form of education" (Myers et al., 1996, p. 18), must see others as supporting a less fully human education. Myers et al. are thus removed from the sense of critical limits that Kantianism imposes, and from the resultant respect for the differentiation and specialization which is constitutive of the modern university. The result may a discordant discord, or a discord limited only by the capacity of the institution to absorb this discord without being destroyed.

One solution to the dilemma faced by the classical liberal arts advocates is to found an entirely new curriculum, where the hierarchies and valuations inspired by classical political philosophy can be constructed without the impediment of the existing university disciplines. St. John's College in Annapolis, Maryland, is a famous example of such a radical curriculum. ${ }^{3}$ There are no departments, majors, minors, or electives. All students follow the same curriculum, which is a classical great books curriculum, beginning in first year with Homer and Plato and ending in fourth year with Wittgenstein and Heidegger. This curriculum is supplemented with laboratories in natural science, where famous experiments in the history of science are repeated, with language tutorials in Ancient Greek and French, and with music tutorials. As a result, all first-year students study the same text at the same time, and so on for each succeeding year. The curriculum, taught in a rigorous fashion, provides a very rich and intense education. It is comparable to the ideals of Schelling, where all forms of knowledge are linked together in an educational process of self-formation.

Despite what may be attractive about the St. John's model, it clearly cannot be generalized to the university system more widely. It remains a highly specific model of education, practised in this form by a very small number of colleges. Within its own realm, it reigns supreme, to the extent that none of the modern university disciplines exist as such at St. John's College. Within the wider university system, the St. John's model occupies an extremely tiny space, as if it were a department of one in a giant multiversity. Following the logic of Derrida's invaginated topology, the model, characterized by the logic of overseeing and transcending all the divisions of the industrial university, becomes a tiny pocket folded into a corner of the much larger system which it ostensibly watches over. Indeed, the St. John's model cannot be more than a supplement to the wider university system of specialized disciplines. Even if we imagined for a moment that the model became widespread or dominant, the graduates of such a system would have to enter graduate schools divided into the existing disciplines and taught by experts trained in the existing disciplines. The disciplinary structure of the modern university can no more be wished away than can the institutions of industrial society.

Returning for a moment to Not for Profit, it can be seen that Nussbaum, as an advocate of very strong and extensive reforms in liberal education is also calling, more or less explicitly, for changes to the wider society. Nussbaum is concerned about the erosion of democracy by the profit motive; St. John's is concerned with excessive specialization and the absence of a shared culture. There are always diagnoses, more or less explicit, of the ills of contemporary society, for which the proposed reforms in liberal education are claimed to be a partial solution. These diagnoses of the wider society are always underdetermined theoretically and overdetermined by the authors' own political preferences. Nussbaum advocates a socially progressive, Deweyan liberalism; Myers et al. advocate classical political philosophy; a left-wing sociologist might advocate for a greater empha- 
sis on social justice and social change. The content and direction of curricular reform cannot be rigorously determined, because the debate itself is overdetermined by pre-existing political and social preferences and philosophies.

At times, the advocacy of reforms in liberal education takes on some of the qualities of a social movement. For example, the American Academy for Liberal Education (AALE) is an organization in the United States for accrediting institutions that offer a liberal arts education. (Myers, formerly vice-president academic of St. Thomas University, is a member of the Council of Scholars of the AALE.) While the organization engages in the standard process of assessing programs for accreditation, its mission is to promote liberal education as a social good or social necessity, referring to itself as a "bipartisan organization dedicated to defending and nurturing excellence in liberal education and assuring access to a quality liberal arts education to all who seek the benefits it portends." This statement is part of the preamble to a "Scholar's Essay" by W. R. Connor (n.d.) hosted on the AALE website. Within the essay, Connor repeats and clarifies one of the central themes of classical liberal arts advocates. Liberal education as they conceive it came into existence in the ancient world in "democratic Athens." It was an education appropriate to the free citizens of a democracy. Two contrasts are intended here. First, free citizens are contrasted with slaves, many of whom had technical skills and positions of responsibility, but who did not have to manage their own freedom, or that of others. Second, "democratic Athens" is contrasted with the neighbouring "piranha states of the Ancient Mediterranean," where the problems of living freely did not arise. In short, living as a free citizen in a democracy required specific skills, knowledge, and dispositions, and the liberal arts provided these "skills of freedom."

Forming citizens for freedom is a heavy load for educationalists to believe they bear. This belief helps to explain the zealous sense of mission that classical liberal arts advocates tend to display. Recall Myers et al.'s (1996) claim that liberal education is the "highest, the noblest, and the most fully human form of education," and that "its final objective is the formation of thoughtful and civilized human beings" (p. 18). The burden of forming citizens for democracy makes it difficult to decide what curriculum is required to meet this objective. What emphasis should be placed on classical antiquity, on medieval Christianity, on early modern political theory, on modern natural science, and on the modern social sciences? The answers to these questions lack rigour. The great books reflex of the classical liberal arts advocates inevitably downplays the achievements of modernity and looks backward. ${ }^{4}$ It is infected with the idea of the cultivation of elites for leadership and command, and it is tempting to move from saying that liberal education is education for freedom, to saying that the majority of people have little taste for such freedom and such education, and instead need wise leadership from those who have such tastes.

Fish's Save the World on Your Own Time (2008) is an exasperated reaction to the overreach of the champions of the classical liberal arts. Instead, Fish implies, we have relatively well-functioning liberal democracies. Let all do their part; let the disciplines and the various institutions do their work. Let the university educate within the parameters of a mature industrial society, and do not project moral and quasi-religious feelings onto university education. Once education is taken over by this kind of moral mission, the debates about what is proper to moral education may never end. The curriculum of St. John's College seems very rich and engaging, but in comparison to Nussbaum's proposals it lacks engagement with non-Western cultures and religions, and with fine art. It also 
lacks engagement with the modern social sciences. The point here is not that the present author could come up with a better liberal arts curriculum, but that there are not agreed upon and rigorous criteria for determining what such a curriculum should include.

In Canada, a recently founded university, with some of the features of the classical liberal arts college, is Quest University, in British Columbia. Quest opened in 2007. Like St. John's College, it dispenses with the normal disciplinary organization. ${ }^{5}$ Courses are organized on the "block plan," which means that a sequence of single courses is taken full time for three-and-a-half weeks each, with the aim of providing a more intensive and focused educational experience. In the first two years, 16 block courses constitute the foundation program, covering the humanities and the natural and social sciences. In the final two years, each student develops a unique research question that guides his or her program. In light of this research question, specialized courses and experiential learning courses are chosen, together with a small number of electives. Overall, the Quest approach is designed to provide a much more cohesive education than the normal majors, minors, and honours approach of most institutions, but it is also considerably more individualized than the extremely cohesive St. John's approach. The curriculum emphasizes the types of courses typical in classical liberal arts curricula, with titles such as Fate and Virtue, Reason and Freedom, and Democracy and Justice, but in addition it has an even heavier emphasis on natural science, including the life sciences, earth sciences, and physics. Quest shares with St. John's the almost complete absence of the normal disciplinary structures, providing the curriculum designers with carte blanche from which to begin, though in the final two years Quest reintroduces more of the standard disciplinary courses as electives. ${ }^{6}$

Few advocates of the classical liberal arts, however, have the opportunity to fashion an entire university curriculum in this way. At St. Thomas University, Myers and Malcolmson, the local champions of curriculum reform in the direction of the liberal arts, had much more modest success. The Great Ideas Programme (recently renamed the Great Books Programme), established in the late 1990s during a period of attempted curricular reform, has a number of features common to classical liberal arts programs. There is a strong emphasis on classical political philosophy, English literature, and moral education, with courses such as Introduction to Great Ideas, The Quest for the Good Life, and Love and Friendship. ${ }^{7}$ Instructors from different disciplines teach in linked courses which attempt to transcend or dissipate disciplinary boundaries. However, the entire Great Ideas Programme is constituted as simply another major, minor, or honours option, as it was realized that neither faculty nor students would support a required program for all students. In other words, it lacks the elements of being taken by all students and constituting a core curriculum which characterizes St. John's College and, to a lesser extent, Quest University. While constructing itself as a core, classical curriculum, the program must compete for students with all other disciplines, and it enrols among the fewest students of all disciplines at St. Thomas. In other words, unable to establish itself as a true core curriculum, it has to offer itself as what could be called an optional core. Other curricular reforms from this period led by the classical liberal arts advocates at St. Thomas University also met with only modest success. Breadth requirements across the whole curriculum were extended to include six credit hours in mathematics or natural science, and/or in fine arts or music. An attempt was made to institute required across-the-curriculum courses in theoretical reasoning and in moral reasoning. These courses were piloted but 
never adopted, because it seemed unlikely that sufficient instructors from the disciplines could be found to teach them. In addition, such required courses would draw students from the existing disciplines, likely leading to resistance from those disciplines.

The case of St. Thomas exemplifies the inherent paradoxes of curricular reform, as refracted through Derrida's analyses. The attempt to integrate knowledge in the search for human wisdom, in the form of a great ideas program, which is reminiscent of Schelling's belief in the organic unity of all knowledge and of self-formation, cannot take hold across the curriculum and remains a tiny pocket within the institution. The attempt to regulate theoretical and moral reasoning across the disciplines, in the form of required courses in these areas-a loosely Kantian gesture-fails to gain traction against the institutionalized disciplinary differences. The point here is not so much to criticize these attempted reforms as to indicate, following Derrida and to a lesser extent Fish, that the disciplinary dissemination, or parcelling out, of reason is not some kind of error that can be wished away, but is a constitutive part of the modern university.

\section{DEFENDING THE HUMANITIES, AND THE NATURAL AND SOCIAL SCIENCES}

The deconstructive approach, which has guided the present analysis, does not lend itself readily to prescriptions for the future. Anything that might look like a prescription coming from the influence of Derrida would be more like a prescription on how not to prescribe, and on how to resist the control of those, who as we have seen, are eager to prescribe for the liberal arts and for the university. But this resistance to principles that prescribe and dictate is itself principled. So something must be said about this principled resistance to principles, which characterizes deconstruction. In a 1983 lecture, Derrida (2004c) asks: "Does the university, today, have what is called a raison d'être?” (p. 129). This French phrase captures the questions Derrida wishes to raise concerning the relation between reason and being, and how this relation connects to the essence of the university. The university was founded on the idea of reason: "We may reasonably suppose that that the university's reason for being has always been reason itself, and some essential connection of reason to being" (p. 135). Derrida points out that there is a history to, and variation within, how reason and its relation to being has been conceived, from the ancient, to the medieval, to the modern world.

The modern era has been dominated by what Leibniz called the principle of reason, which had several formulations. The two most important of these are, first, "nothing is without reason, no effect is without cause," and, second, for every true proposition, a reasoned account is possible, or reason can be "rendered." 8 The principle of reason also implies, Derrida argues, a responsibility to "render reason." Reasons or causes must be found and given. That is, the principle of reason places us under an obligation to give reasons or to "render reasons." Most research in the modern university, suggests Derrida, following Heidegger, is founded on the principle of reason, or rather on a dominant interpretation of the principle of reason, which in effect turns the world into an object to be dissected, explained, and analyzed. In other words, the world is divided into different regions of being, or regional ontologies, and the disciplines then pursue the investigation of each region according to their ontological assumptions about their region of being, in accordance with the general spirit of rationality captured by the principle of reason. 
The principle of reason thus captures the spirit of the modern university, where the regions of reality are objectified, over and against the rational subject who investigates the rational causes of each region of being. These practices constitute the modern disciplinary university devoted to research, which classical liberal arts advocates find too specialized and too technical, and insufficiently concerned with the pursuit of wisdom. We have already seen that Derrida is not opposed to this modern conception of the university. To be opposed to it would be in effect to have a quixotic opposition to modernity itself. But neither is Derrida entirely satisfied with the complete dominance of the principle of reason. This position is in contrast to Fish, who vigorously and almost gleefully supports the disciplinary division of labour, and the abstention from moral and political questions that goes with it.

What, then, are Derrida's concerns, and how are they different from those of the liberal arts advocates? Derrida suggests that reason has a richer history than what is captured by the principle of reason, or that there is more to reason than the version of it formulated in the principle of reason. As we have seen, the principle of reason is installed at the heart of the modern university, and is at the centre of modern techno-science. For Derrida (2004c), we are obliged to follow this principle: "To respond to the call of the principle of reason is to 'render reason,' to explain effects through their causes, rationally; it is also to ground, to justify, to account for on the basis of principles (arche) or roots (riza)" (p. 137). But, Derrida suggests, in addition to answering the call of the principle of reason to give reasons, there is also an implied call to ask about the principle of reason: "What grounds this principle which is itself a principle of grounding?" "Are we to use reason to account for the principle of reason? Is the reason for reason rational?” (p. 137). Is it obeying or disobeying the principle of reason to ask questions about it in turn? It is neither obeying nor disobeying it. We are entering into a deconstructive zone here, where the opposition yes/no finds itself suspended. Instead, deconstruction will excavate the suppositions built into the principle of reason. Derrida describes these suppositions as follows: "The modern dominance of the principle of reason had to go hand in hand with the interpretation of the essence of beings as objects, an object present as representation [Vorstellung], an object placed and positioned before a subject. This latter, a man who says 'I,' an ego certain of itself, thus ensures his own technical mastery over the totality of what is" (p. 139).

Deconstruction can thus be seen to be partly at odds with a dominant techno-scientific and empiricist self-understanding of modernity, where science would be presumed to be the ultimate arbiter of truth and reality. However, deconstruction is equally at odds, as we have seen, with the liberal arts schema borrowed from classical political philosophy, where the thinker as leader directs the masses who act rather than think. Indeed, Derrida (2004c) constantly warns about the risk that the types of questions he pursues could reopen this ancient hierarchy between the leisured class of thinkers and the ordinary "doers," and is at pains to minimize this risk. To summarize, Derrida's deconstructive approach questions and destabilizes the self-understanding of techno-scientific modernity, but just as much questions and destabilizes the metaphysical hierarchy presupposed by the liberal arts.

Lacking space for further elaboration of these questions here, let us simply note that the type of deconstructive response Derrida favours will, as he himself says, find a particularly receptive and central place in the humanities (see, for example, Derrida, 2001). But it 
will not only be found there. Something approaching a deconstructive type of inquiry may also take place in the social sciences, in the fine arts and performing arts, and even in the natural sciences. Deconstruction does not occur only once or in one place. If we should respond to and question the principle of reason, up to and including questioning of the questioning form of thinking sanctioned by the principle of reason, this questioning/responding will not take place just once or in just one form. Each science, each discipline, and each mode of inquiry founds or grounds each time its own ontology and its own rationality. So if this grounding activity of the principle of reason takes place more than once and in more than one place, the deconstructive questioning of, and responding to, this grounding, must necessarily also take place more than once and in more than one place. Reminiscent of the displacements of philosophy Derrida detects in Kant and Schelling, the deconstructive response to the modern form of rationality will also be disseminated and scattered: it will not be grounded in any one place, time, discipline, or procedure.

Derrida was involved in the late 1970 s and early 1980 s in helping to found a new philosophical institution in France, the Collège International de Philosophie. ${ }^{9}$ A central idea of the new college was that philosophical research would cut across disciplines, including the natural sciences, the social sciences, and the arts and humanities, and that it would seek out and discover new philosophical problems within the sciences, arts, and even the professions. A second central idea was that the practice of philosophy in the college would be open to anyone with a proposal that was deemed suitable, regardless of whether they were philosophers by discipline, and regardless of their degrees or university affiliation. Whatever the precise merits of the interventions of Derrida and his colleagues, these interventions were notable for being attuned to the reality that philosophy could no longer pretend to be a master discourse, and that problems of a philosophical order were already being elaborated in the existing disciplines. A new philosophical practice would thus have to exceed the boundaries of professional philosophy and of philosophy proper; that is, philosophy as a self-contained and magisterial discipline.

Some tentative concluding comments can be made here, though there are no prescriptions to be drawn from Derrida's work, and the context in Canada is radically different to Derrida's France, and even substantially different to the situation of the humanities in the United States, where Derrida did some of his work and where the debates about the liberal arts are most developed and most germane. First, academics from across the disciplines should be called on to defend university autonomy, in the broad sense of inquiry and research free from external control. Such a call to defend freedom of inquiry, and fundamental as opposed to directed research in all disciplines, is a rallying cry to allow otherwise disparate disciplines and interests to coalesce and cooperate. But this defence must be of not only the humanities, but also the social and natural sciences. ${ }^{10}$ What needs to be defended is the liberal arts and sciences; that is, the enlightenment tradition of free scientific and scholarly inquiry. Given this aim, the activities of the classical liberal arts advocates are counterproductive. With their elevation of classical political philosophy, and their claim to judge the wisdom, or lack thereof, of the natural and social sciences, they divide the university, rather than uniting different sectors in the shared interest of defending freedom of thought, research, and teaching. Note also that a wide-ranging defence of freedom of inquiry should preserve the freedom, not only of the major disciplines, but also of liberal arts programs like the St. Thomas University Great Ideas Programme, 
or for deconstructive types of inquiry that would question and destabilize disciplinary assumptions. However, the liberal arts champions will have to give up their desire for hegemony and rule, and take their place as one of a large number of programs, none of which has the right to claim to rule over the others. They should give up this claim to rule over others, not merely as a pragmatic concession to the prevailing balance of forces, but also on principle.

There is also a strong tradition in Canada of faculty unions and a national faculty union, the Canadian Association of University Teachers. These unions have been very effective in defending university autonomy, and in resisting managerialism and corporatization (e.g., Turk, 2000). The classical liberal arts champions have generally been unable to ally themselves with these excellent organizations. The metaphysical assumptions of classical political philosophy lead liberal arts advocates almost automatically to sympathize with the management hierarchy whose leadership role they believe to be natural, and which they wish to partake of, and to be suspicious of faculty unionization. They interpret unionization as supporting their presupposition that natural and social scientists are merely technical workers, and not real thinkers, philosophers, and seekers of wisdom. Much needs to be done to defend and improve the modern university. Liberal arts champions will be better able to contribute to this effort if they come to a principled recognition of their own limits.*

\section{NOTES}

1. Such defences and diagnoses are appearing in great numbers. Fish (2010) recently listed 12, and he said the number could easily be doubled. In addition to the works discussed in this paper, the following sources suggests some of the diversity of perspectives recently brought to the issue: business/managerial (Knapp \& Siegel, 2009), Deweyan pragmatic humanism (Gould, 2003), a university president (Bok, 2003), left wing/faculty union (Nelson, 2010), right wing (Horowitz, 2010), and a defence of classical liberal education (Roche, 2010).

2. The translation of Kant in Derrida's essay as quoted here differs slightly from the published English translation of Kant cited here.

3. Information on the curriculum at St. John's College can be found at http://www.stjohnscollege.edu/academic/main.shtml. See also Miller (1998) for a sympathetic but critical history of the development of the St. John's curriculum.

4. The fundamental goal of classical liberal arts advocates is moral and political. For such advocates, all education must fundamentally be moral education. The content of the curriculum must be determined by the moral effects this curriculum will produce. The analysis of what is required for moral education in turn depends on a political evaluation of the nature of the wider society. An instructive comparison and contrast to the analysis of Myers et al. is Emile Durkheim's classic account from the early 1900s, Moral Education (1961). Durkheim shares the classical viewpoint that education is what forms us, and makes us human, or civilized. However, for Durkheim moral education should take place under the auspices of the new discipline of sociology, which would replace classical education with the spirit of modern science. Thus a similar evaluation of the need for moral education leads to very different recommendations for the content of that education. 
5. Information concerning Quest University and its curriculum can be found at http:// www.questu.ca/.

6. It should also be noted that Quest is a private university, one of very few in Canada. In this respect, it bears comparison to the recently established New College of the Humanities in England, a private college that has drawn criticism for offering an elite education at very high fees. A common theme of defenders of the classical liberal arts, as we have seen, is that education for freedom or virtue is a luxury not suitable for everyone.

7. For the Great Ideas Programme, refer to http://w3.stu.ca/stu/academic/ departments/great_ideas/default.aspx.

8. Derrida (2004c, pp. 135-136) cites Heidegger (1996, pp. 21-22), who in turn cites Leibniz (1995, p. 75).

9. See Châtelet, Faye, \& Derrida (1998), Fynsk (2004), Leitch (1986), Wortham (2006), and many of the essays in Derrida's two-volume Who's Afraid of Philosophy (2002, 2004).

10. On defending freedom of research in the pure and applied sciences, see, for example, Forer (2010) and Olivieri (2000).

\section{REFERENCES}

Bok, D. (2003). Universities in the marketplace. Princeton: Princeton University Press.

Châtelet, F., Faye, J.-P., \& Derrida, J. (1998). Le Rapport bleu: Les sources historiques et théorique du Collège International de Philosophie. Paris: Presses Universitaires de France.

Connor, W. R. (n.d.). Liberal arts education in the twenty-first century. AALE Occasional Papers in Liberal Education \#2. Retrieved from http://www.aale.org/aale/ pubs.html

Derrida, J. (2001). The future of the profession or the university without condition. In T. Cohen (Ed.), Jacques Derrida and the humanities: A critical reader. Cambridge: Cambridge University Press.

Derrida, J. (2002). Privilege: Justificatory title and introductory remarks (J. Plug \& others, Trans.). In J. Derrida, Who's afraid of philosophy: Right to philosophy 1 (pp. 1-66). Stanford: Stanford University Press.

Derrida, J. (2004a). Mochlos, or the conflict of the faculties (J. Plug \& others, Trans.). In J. Derrida, Who's afraid of philosophy: Right to philosophy 2 (pp. 83-112). Stanford: Stanford University Press.

Derrida, J. (2004b). Theology of translation (J. Plug, Trans.). In J. Derrida, Who's afraid of philosophy: Right to philosophy 2 (pp. 64-80). Stanford: Stanford University Press.

Derrida, J. (2004c). The principle of reason: The university in the eyes of its pupils (J. Plug, Trans.). In J. Derrida, Who's afraid of philosophy: Right to philosophy 2 (pp. 129155). Stanford: Stanford University Press.

Durkheim, E. (1961). Moral education (E. K. Wilson, Trans.). Glencoe, IL: The Free Press.

Fish, S. (2008). Save the world on your own time. Oxford: Oxford University Press. 
Fish, S. (2010, November 8). The woe-is-us books. The New York Times. Retrieved from http://www.nytimes.com/adx/bin/adx_click.html?type=cookie\&pos=Position1B

Forer, A. (2010). A requiem for fundamental biology. In J. Newson and C. Polster (Eds.), Academic callings: The university we have had, now have, and could have. Toronto: Canadian Scholars' Press.

Fynsk, C. (2004). The claim of language: A case for the humanities. Minneapolis \& London: University of Minnesota Press.

Gould, E. (2003). The university in a corporate culture. New Haven \& London: Yale University Press.

Heidegger, M. (1996). The principle of reason (R. Lilly, Trans.). Bloomington \& Indianapolis: Indiana University Press.

Horowitz, D. (2010). Reforming our universities: The campaign for an academic bill of rights. Washington, DC: Regnery Publishing.

Humboldt, W. Von. (1970). On the spirit and the organizational framework of intellectual institutions in Berlin. Minerva, 8, 242-250. (Original work published 1809)

Kant, I. (1979). The conflict of the faculties (M. J. Gregor, Trans.). Lincoln \& London: University of Nebraska Press. (Original work published 1798)

Knapp, J., \& Siegel, D. (Eds.). (2009). The business of higher education (Vols. 1-3). Santa Barbara, CA: Praeger.

Leibniz, G. W. (1995). Philosophical writings (G. Parkinson, Ed.). London: Everyman.

Leitch, V. (1986). Research and education at the crossroads: A report on the Collège International de Philosophie. SubStance, 15(2), 101-114.

Miller , R. (1998). Education for everybody: Great books and the democratic ideal. In R. Miller, As if learning mattered: Reforming higher education (pp. 85-120). Ithaca \& London: Cornell University Press.

Myers, R., Malcolmson, P., \&O’Connell, C. (1996). Liberaleducation and value relativism: A guide to today's B.A. Lanham, New York, \& London: University Press of America.

Nelson, C. (2010). No university is an island: Saving academic freedom. New York \& London: New York University Press.

Nussbaum, M. (2010). Not for profit: Why democracy needs the humanities. Princeton \& Oxford: Princeton University Press.

Olivieri, N. (2000). When money and truth collide. In J. Turk (Ed.), The corporate campus: Commercialization and the dangers to Canada's colleges and universities (pp. 53-62). Toronto: James Lorimer.

Roche, M. W. (2010). Why choose the liberal arts? Notre Dame, IN: University of Notre Dame Press.

Schaffer, E. (1990). Romantic philosophy and the organization of the disciplines: The founding of the Humboldt University of Berlin. In A. Cunningham \& N. Jardine (Eds.), Romanticism and the sciences (pp. 38-54). Cambridge: Cambridge University Press. 
Schelling, F. J. (1966). On university studies (N. Guterman, Ed.) (E. S. Morgan, Trans.). Athens, OH: Ohio University Press. (Original work published 1803)

Turk, J. (Ed.) (2000). The corporate campus: Commercialization and the dangers to Canada's colleges and universities. Toronto: James Lorimer.

Wortham, S. (2006). Counter-institutions: Jacques Derrida and the question of the university. New York, NY: Fordham University Press.

\section{CONTACT INFORMATION}

Colm Kelly

Department of Sociology

St. Thomas University

Fredericton NB

Canada E3B 2G8

kelly@stu.ca

Colm Kelly, PhD, is Associate Professor of Sociology at St. Thomas University in Fredericton, New Brunswick. His interests include social theory, deconstruction, ethnomethodology, and the modern university. 